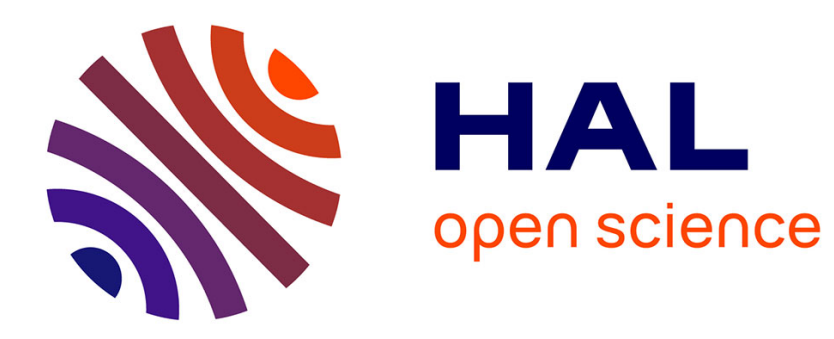

\title{
A political history of Bektashism in Albania
}

Albert Doja

\section{To cite this version:}

Albert Doja. A political history of Bektashism in Albania. Politics, Religion and Ideology, 2006, Totalitarian Movements and Political Religions, 7 (1), pp.83-107. 10.1080/14690760500477919 . halshs00425475

\section{HAL Id: halshs-00425475 \\ https://shs.hal.science/halshs-00425475}

Submitted on 21 Oct 2009

HAL is a multi-disciplinary open access archive for the deposit and dissemination of scientific research documents, whether they are published or not. The documents may come from teaching and research institutions in France or abroad, or from public or private research centers.
L'archive ouverte pluridisciplinaire HAL, est destinée au dépôt et à la diffusion de documents scientifiques de niveau recherche, publiés ou non, émanant des établissements d'enseignement et de recherche français ou étrangers, des laboratoires publics ou privés. 


\title{
A Political History of Bektashism in Albania
}

\author{
ALBERT DOJA \\ University of Limerick, Ireland
}

\begin{abstract}
Heterodox mystics and heretics of any kind become sometimes dangerous and other times reliable, depending on political situations, as was the case with the Bektashis. The system of beliefs and practices related to Bektashism seems to have corresponded to a kind of liberation theology, whereas the structure of Bektashi groups corresponded more or less to the type of religious organisation conventionally known as 'charismatic groups'. It becomes understandable, therefore, that their spiritual tendency can connect with and meet social, cultural and national perspectives. In turn, when members of the previously persecuted religious minority will acquire a degree of religious and political respectability within society at large, the doctrines of heterodoxy and liberation theology fade into the background. In the end, the heirs of the heterodox promoters of spiritual reform and social movement turn into followers and faithful defenders of a legitimate authority. They become the spokespeople for an institutionalized orthodoxy whose support is sought by the political regime.
\end{abstract}

\section{Introduction}

Religious studies specialized in Bektashism, being largely the domain of either Orientalists or religious scholars, remain stuck somewhere between ethnocentrism, empiricism, historicism and literalism, and thereby have brought little distinctively anthropological and sociological analysis to bear, successfully, on the practical realities and political ideologies of religions. They tend to be affected by what Roland Barthes called the "virus of essence", towards a folklorist paradigm of Reliktforschung, ${ }^{2}$ concerned with a search for the remainders of ancient times. The main interest of such unanalytical approach, which often piles up uncritically all kinds of trite evidence, seems only to be in correcting either the mistakes of Western specialists or the presumptions of local scholars on one or another point of details.

After umpteen "preliminary" accounts of research regarding Bektashism, suggestions for further research are still advocated on the single account of the relationship between the different religions present in Anatolia or in the Balkans and their development. A supposed substratum of folk religion, the highly syncretistic character or the exclusive heterodox nature of Bektashism are unquestionably assumed as continuous reactions to centuries of foreign dominance and antagonistic outside influences, leading to an immutable inertness and preservation of archaic features deemed to characterize cultural and religious life. Taking into 
account this background, Bektashism has deserved special attention as a religion that incorporated so many archaic traits and developed in Albania an independent character which serves as a paradigmatic example for these forces of inertness and resistance.

To be sure, historians of the Ottoman Empire have become increasingly conscious of the existence of political debate within the Ottoman ruling class and of political struggle between different sectors of the Ottoman society. In certain instances there is also a focus, even though somewhat timidly, on the relationship between ideology and politics in the Ottoman Empire. It is therefore not surprising that questions of legitimation have gained a new importance, and the Bektashis and other dervishes have come to be seen as the providers of many things. They converted nomads from shamanism to Islam, extended social and emotional support to new converts, particularly the Janissaries, provided food and shelter to travellers, proposed concrete saints for popular piety to focus on, and at the end of the nineteenth century, constituted a source of support to the Young Turks. Many painstaking efforts have been made to show that certain Bektashis "could provide a source of legitimation against an established government" or even "prove the existence of a civil society in the Ottoman Empire". 3

Eventually there are perhaps the modern views of the nation-state and all of its institutionalized mythologies that over the last one hundred years have confused, erased, desecrated and demolished our understanding of the local definitions and categories of group identity, as articulated in everyday life. In these conditions many supposedly well established facts concerning historical developments of Bektashi doctrine and organization have to be severely contested and questioned, as resulting from the deliberate use of myths for political, ideological and religious purposes.

A series of historical incidents like the sudden appearance and rapid spread of the Bektashi group of dervishes during the thirteenth and fourteenth centuries, their transformation into a powerful Sufi order during Ottoman times, and the developments to which Bektashism has been subjected in late Ottoman period as well as in independent Albania and in modern Turkey, still remain issues that require an explanation. This article, limited to the development of Bektashism in Albania, is part of a larger critical and explanatory analysis, aiming at revealing that these variations in the course of history make of Bektashism the mystical order of Islam that probably best exemplifies a transformational pattern involving all its theological, ideological, cultural, social, and political aspects.

Heterodox religious movements and the institution of new forms of religion, as in the case of mystical orders of Islam like the Bektashis, are decisive for understanding the history of religions in Southeast European area. This in turn could bring forth insights for understanding the current situation in which group identities are being negotiated and redefined. While mystics do not partake in, or directly express class struggle, their heterodoxy, over and beyond the intensity and power of their beliefs or the radical character of their opposition to the established religion, did always and still necessarily does crystallise political, social and cultural discontent which, is in turn, very often ethnicised along nationalist lines.

The point is not only that religion as a cultural symbolic system uses political and other resources that show a power base. More importantly, religion, in its own field, has rather a symbolic structure, which, as Bourdieu put it, ${ }^{4}$ reproduces the distribution of resources and power from the non-symbolic mundane field in a 
transformed form. To better appreciate this we must arguably begin by attempting to comprehend the underlying significance of the structures of religious representation and mediation, and the implication of their change in support of either cultural orderings or order-questioning projects in human society.

\section{Overview}

The origin of the Bektashi order of dervishes belongs to the many Sufi movements of Islam that developed in the Middle East from the eleventh and twelfth centuries onwards. ${ }^{5}$ The name of the order is derived from the legendary founder Haji Bektash, originally coming from Khorassan in north-east Iran, and living in Anatolia in the second half of the thirteenth century. ${ }^{6}$ The description of his Vilâyet-Nâme corresponds to that of a typical wandering dervish, similar to Iranian Kalenders or Anatolian Abdals. The dervishes who followed him are called Abdal and from the very start, he is called "Pir" (leader) of Anatolian Abdals. Apparently Bektashism must have started during the thirteenth and fourteenth centuries as a mixture of shamanism inherited from the Turcoman tribes of Khorassan, mixed with popular beliefs in such a way as to appeal to villagers and the lower class of the Anatolian population.

In the region of origin of the Turcoman tribes and the followers of Haji Bektash, Bektashism must have mingled with local pre-Islamic beliefs, and it is not surprising that besides different Sufi doctrines and practices, many different religious traditions contributed to the development and appearance of Bektashism, leading specialists to claim that the Order did not have a well defined theology and could accommodate much local influence, its fundamental character being an allencompassing syncretism. ${ }^{7}$

Bektashi doctrines are characterized by a Shiite and pantheistic character, even though Shiite influence may be a relatively late development of the sixteenth century. The Bektashis are also considered to have combined in their order a considerable number of doctrines and practices of heterogeneous origins, including not only Shiism and Sufism but also preserving pre-Islamic and non-Islamic beliefs and customs originating in Christianity and antique religions as well as ancient Turkic elements. ${ }^{8}$ As such traditions, the Bektashis incorporated anthropomorphic and cabbalistic doctrines of letter and number symbolism that can be traced to Hurufism ${ }^{9}$ combined with an extremist Shiite credo that linked devotion to the divinity of Ali with beliefs in anthropomorphism, the manifestation of God in human form, reincarnation and metempsychosis. ${ }^{10}$

The prevailing syncretism between ancient, pre-Islamic Turkic, and Islamic elements in Bektashi lore is further argued on the account of the encounter of preIslamic Turks with 'high religions' in Central Asia and the position of the Bektashis at the crossroads of different cultures, while the question of shamanic remainders is henceforth claimed to be far less important than usually assumed. ${ }^{11}$ Arguably, the many traits of Christianity that had been incorporated into Bektashism and other major Sufi groups and dervish orders like the Mevlevi, contributed significantly to the shaping of popular Islamic beliefs, thus facilitating the conversion to Islam of the Christian populations in Anatolia and the Balkans, which previously had only been superficially Christianized.

It is claimed, in particular, that the Bektashis preserved many traits of oppositional movements and heretic groups, and shaped them into a synthesis during times of a mutual penetration of Turkic and Byzantine cultural traits. There is 
clear evidence for the participation of Haji Bektash himself and his adherents in the Turcoman uprisings against Seljuk rule in 1239-1240, the so-called Babaî revolt, ${ }^{12}$ even though, as in many other cases concerning Sufi hagiography, Haji Bektash was not the actual founder of the order but a patron saint chosen at a later date. There remains probably very little resemblance between Turcoman beliefs of Haji Bektash's time in thirteenth century and those that formed the heterodox but sophisticated doctrines at the turn of sixteenth century when the Bektashis were organized as an established Order of dervishes. Among other things, during Ottoman-Safavid wars in sixteenth century, the connections between the Bektashi-Kizilbas and the Safavid movement, as well the later development of the Safavids into adherents of Shiism, are now well established. ${ }^{13}$ It is after this period that Bektashism came to be characterized by a distinctive Shiite and pantheistic character.

Primarily colonizing dervishes, in charge of Turkicization and Islamicization of countries conquered by the first Ottoman sultans, shortly after the organization of the order in sixteenth century, the Bektashis established themselves as one of the most influential dervish orders during the Ottoman period from the seventeenth and eighteenth centuries. Not only were the Bektashis an instrument of the Ottoman propaganda in conquered countries, but they enjoyed a certain political importance in the Ottoman Empire, and even imposed themselves on some weak or mystic sultans, especially when they were closely connected with the Janissary troops, the instrument of Ottoman military power. To what degree the rise of the Bektashi order can be attributed to its links with the Janissaries is a matter still open for investigation, as disputation rages among specialists about the role of Bektashis in the formation of Janissaries as an elite army. It is considered, however, that the Bektashis constantly encouraged and dominated the Janissaries by traditionally providing their religious guides.

When after repeated revolts and rebellions the Janissary troops were finally dismissed in 1826 with resisting forces being massacred, this meant that also the Bektashis were subject to state suppression and had to move to the margins of the Empire. A hundred years later, after the establishment of modern Turkey after World War I, the Bektashi Order was again subject to state prosecution until 1925 when it was officially abolished altogether with the other dervish orders in the newly founded Turkish Republic. These trials and tribulations allowed Bektashism to develop a non-conformist and antinomian doctrine to the point of being often depicted, despite its deep mystical roots, as a progressive current within Islam.

Since the sixteenth century, adherents of the Safavids and other heretics were deported from Anatolia to Rumelia and integrated into the Bektashi order thus laying ground for the presence of Shiite Islamic elements in southeast Europe. From later developments of Bektashism under Ottoman Empire it becomes obvious that Albania often served as a kind of exile for the adherents of the Bektashi faith, although the origin of the Bektashis in Albania remains still obscure. Reliable evidence indicates that their emergence cannot be dated earlier than the turn of seventeenth century, ${ }^{14}$ which is also consistent with the rather late Islamicization of the Albanian population. Many painstaking efforts and fanciful claims, however, mostly grounded in legend and hagiography, have tried to push back their origin in Albania, even far before the appearance of the Ottomans in Balkans. ${ }^{15}$

At any case, besides Sunni Islam, mystical forms of Islam spread in the country, directed at an individual and direct experience of the presence of God and thereby also deliberately making use of altered states of consciousness, such as ecstatic 
dance (sema) and recitation (zikr). Many of them must have been adherents of the order of Bektashis and it is likely that they were present in Kruja, central Albania, in the last decades of sixteenth century. ${ }^{16}$ However, if they were not exclusively related to the solders of the local Ottoman garrison, it is unlikely they might have had any significant impact on a local population not yet Islamicized or at least with an "Islam only feebly represented at this early date". There is general agreement that after its noticeable presence in the second half of seventeenth century, Bektashism gradually became more and more deeply rooted in Albania during nineteenth century.

One reason for this was the fact that the Bektashis were spared the suppression that the order had to face in Anatolia and other core areas of the Ottoman Empire in the first quarter of the nineteenth century (1822-1826). If the Janissary army and the Bektashi Order were to be formally abolished, the abolition could only be effective in Istanbul and the provinces where the central Ottoman administration had a direct authority and power. As the Albanians remained outside of these territories and the Ottoman authority was insignificant in the Albanian area during this period, the Bektashi continued to live undisturbed in Albania, in a far better and more secure position than their fellows in Turkey. In that way, in Albania the Bektashi are said to be numerically important, and Albanian dervishes are frequently found in convents outside their own country. Many high Bektashi dignitaries, including sometimes even the supreme leader of the central institution, are often thought to be of Albanian origin. When Turkey decreed the definitive abolition of all mystic orders in 1925, the Bektashi general headquarters once again took refuge in Albania.

In Albania, in several instances religion has played a unique role compared to the rest of Europe. Not only was Albania, like Bosnia, one of the only European states with a majority converted to Islam, but Albania is also known as the only country worldwide where atheism was declared a compulsory state doctrine in 1967. Still, the resulting prosecution of all religious congregations and the oppression of religious activities is not the only remarkable fact about religious life in Albania.

Generally, in Southeast Europe and elsewhere ethnicity is closely linked to the adherence to a specific religion. Unlike any other nations in Southeast Europe, Albanians traditionally did not adhere to a single faith. Among Albanians, as an exception from the rule, four different confessions prevailed: Catholicism mostly in the north, Orthodoxy mostly in the south, Sunni Islam mostly in the central and eastern parts of the Albanian inhabited areas, and Bektashism mostly in the south. Such a situation must go thereby somehow toward contesting the fixed adherence to one specific type of religion. Due to missionary efforts by Western and Middle Eastern congregations alike, even nowadays loyalty to one specific religion in Albania is fluid and might be divided. It is, for example, not uncommon that a contemporary Albanian might declare him- or herself to be a 'Protestant Muslim' if he or she has converted to one of the several Protestant congregations being engaged in missionary work in the country.

Islam did not seem to be very deeply rooted in Albania until the nineteenth century and it is usually assumed that this was also the case with Christianity some centuries earlier, which of course must have facilitated conversion to Islam. In addition, there is general agreement about the fact that religion in Albania tends to be syncretistic. Many traits of Christianity survived among Muslim converts in form of the so called Crypto-Christianity. It is little surprising that a typical feature of the 'religious landscape' in Albania seems to have been the people called laramanë, 
literally 'spotted' or 'coloured', referring to the fact that many Albanians adhered to more than one confession at the same time. In relation to this somewhat divertive and fluid character of religions, Albanians are often depicted as showing remarkable superficial religious feelings. Not only people's faith changed according to political opportunism, but religious services turned into recreational events for small talk and gossip rather than serious worship.

Albanians have never strictly adhered to many religious duties and practices. Prohibition of alcohol was never observed by Albanian Muslims, daily prayer (namaz) was ignored and ritual fasting (ramadan) hardly observed. Of course, they kept the Koran in their house, helped the poor, performed the rituals for the dead, and went on pilgrimage to visit the tombs of Muslim holy men. There are numerous accounts of Christians and Muslims visiting the sacred sites of each others' congregation. If we judge by the ex voto on the walls of shrines, a Christian custom also adopted by Muslims, miracles are believed as never before. Not only are these practices still observed today, but some religious celebrations are becoming festive occasions for the Albanian family. No Muslim family would miss the bajram meal or fail to sacrifice a lamb, which is very similar to the way people celebrate Christmas in the West and in Albania alike. People in modernday Albania attend religious ceremonies regardless of which faith they belong to, as a form of social gathering. Therefore it might be assumed that a common religious substratum exists for all four religions in Albania, and that a typical Albanian form of religiosity developed.

Religious conversion and politics, as I showed elsewhere, ${ }^{17}$ relate primarily to a collective history, which embraces social and cultural communities, or more precisely, members of a lineage, family, a village community or a larger territorial group. An individual converts to Islam or to Christianity because he or she belongs to a social network. Conversion and religious belonging or affiliations are therefore part of a process of socialization through the pursuit of a collective identity. Collective representations and beliefs, rites, customs and ceremonies are considered part of the official religion - Christianity or Islam accordingly - of a given local community or social network, irrespective of whether a particular cultural trait does or does not form part of the world religion in question. They are categorized collectively not as religious traits of an established world system but as 'an ancestral legacy of traditions and customs'. Belonging to a religion means belonging to a social group. Although the individual may share group prejudices towards other religious groups, the essential group values are defined by a system of kinship and alliance, of solidarity and hostility, of status and social position, which I considered elsewhere, ${ }^{18}$ as being common to all Albanians. Being Muslim or Christian is based on the particular family, kinship, territorial, or social group, which by tradition relates to religious 'belonging' or adherence. It is not based on a specific belief system or religious conviction; rather it is grounded in the social culture. Religion is a conformity, which is transmitted throughout the community.

Taking into account the specific Albanian religious climate, the establishment of Bektashism in Albania has deserved special attention because of the concordance to the pantheistic and unorthodox character of the Bektashi faith. Acceptance of Bektashism in Albania was largely facilitated by the fact that Bektashi syncretism already combined pre-Islamic and Shiite elements with Christian elements. When Bektashism established itself in Albania, these beliefs must have been quickly replaced by Albanian popular traditions. In addition, Bektashi 
tekkes were mostly situated outside of the Albanian towns, which made it possible for the order to maintain its rural character with most of Albanian dervishes having their roots in the local peasantry.

In that way Bektashism came to be perceived as the purest expression of Albanian religiosity and the conservatory of Albanian traditions, to the point of being considered as the only truly national religion, and it is no surprise if Bektashis might have played an important role in the national awaking of Albania in the second half of the nineteenth century. Specialists speak of the 'solidification' of a properly Albanian Bektashism in the western confines of Ottoman Empire, with elements of Albanian nationalism being integrated into Bektashi doctrine, especially in the southern parts of the country where most of the Bektashi tekkes were situated. ${ }^{19}$ Whether or not there was significant Bektashi influence on the nationalist movement, it becomes quite clear that a decisive national Albanian character of the order was further fostered in the course of the twentieth century.

\section{From liberation theology to hierarchical surrender}

Essentially, the early Sufi and Bektashi groupings corresponded to the sphere of spiritual experience which ran parallel to the mainstream of Islamic consciousness, deriving from prophetic revelation and comprehended within the orthodox, codified, and systematic theology of the Sharia. In this non-conformist religious experience there was no room for a clear-cut separation between man and the divinity, such as that propounded by the orthodox, legalist Sunni dogma. When mystical union with God was not quite the goal sought, it was the cult of the miracle-working saints, living or dead, through worship of their tombs, which prevailed in the religious fervour of these heretic and heterodox religious groupings. They were therefore integrated by spirit and aim rather than by any formal organization, and were in fact very loose organizations.

Haji Bektash himself, for instance, carried out a life of a wandering hermit during most of his life and he did not seem to have been a prominent character. He did not even seek to found any order or to have disciples during his life. He remained the eponym of an order he did not found himself, and was quite unconscious of the impact he was going to have; his success being achieved after him and in spite of him.

In these conditions, the intensity of religious life prevails over its extension, and salvation becomes a personal affair rather than a relationship with some gracedispensing agency. Participation in the spiritual community comforts the individual need to oppose or transcend society, raising one temporarily into a timeless, supernatural experience. Legalistic orthodox religion - not concerned with the exercise of a pastoral office, and possessing neither means nor agencies for emotional outlet and few for free intercession - had little to offer to such human deeper needs. The legal religion fulfilled a social far more than a spiritual function, and it was the function of heterodox movements, parallel and often in opposition to the orthodox institution, to mediate the inner aspect of religious experience. Heterodox or heretic movements and mystical orders embodied in themselves the whole mysterium fascinans of the age - revealed, esoteric, mystical and emotional religion.

To this extent, following innovative approaches within the field regarding early Sufism in eleventh and twelfth centuries, ${ }^{20}$ we may be correct in considering a first 
aspect of Bektashism as a reaction against the external rationalization of religion in law and systematic theology, aiming at spiritual freedom whereby human intrinsic and intuitive spiritual senses could be allowed full scope. In its earlier developments during the thirteenth and fourteenth centuries Bektashism must have been a subjective expression of personal religion in reaction to the expression of religion as a communal matter. It must have been an assertion of a person's right to pursue a life of contemplation, seeking contact with the source of being and reality, over and against instituted religion as based on authority and legalistic morality.

In the face of economic, social and ideological upheaval, the most radical mystics have always adopted attitudes cultivating distance from mainstream society. Their watchword was the desire to be outsider in a world claimed to be corrupt and led astray by bad guides. Mystics of this sort were not simply opponents of the ruling classes. They were intent on going against social norms as well, and this character must have been emphasized in the course of history at each time when the Bektashis have been subjected to political state oppression. To remain within the classic history of Bektashism in Ottoman Turkey, this happened specifically after the Ottoman-Safavid wars in the first half of sixteenth century, after the suppression of Janissary troops in the first half of nineteenth century, after the abolition of dervish orders in the first half of twentieth century. Viewed in this light, the structure of Bektashi groups corresponded more or less to the type of religious organization conventionally known as charismatic groups.

As long as heterodox theology developed from common experience of both spiritual knowledge and suffering, it is possible to understand how covenantal structures of divine mediation corresponding to specific stages of Bektashism and Sufism gain a different meaning if the intermediary hierarchy is to be found in the conceptualization of the divinity or in the organization of the worldly human society. One of the functions of religion as a cultural system, especially in Christianity and Islam, is to serve as a mediating representation between powerless earthly creatures and an all-powerful God located in heaven. Mediation would make it possible for the heavenly divinity to intercede on behalf of humans on earth. Muslims, and in particular apologists of Sufism, assert that their Islam is more than religion and articulate its techniques and master-disciple relations as reflections of those of God to humans.

Following a structural hypothesis suggested by Edmund Leach, ${ }^{21}$ I have argued elsewhere that a crucial factor for understanding the communication between humans and God lies in the fact that the hierarchical model of religious mediation corresponds to the dogma of orthodox faiths, while the model in which all hierarchies are denied, in its real embodiments, is closely linked to millenarian and mystical beliefs and to the development of heresies and heterodoxies, ${ }^{22}$ such as those related to Bektashism. The former model may well support an established, hierarchical power, whereas the latter corresponds to an oppressed or deprived minority, seeking justification of its revolt against the established authorities.

According to this model, the establishment of a political hierarchy within society goes hand-in-hand with the introjection of a unified conception of divinity, that is, a pure monotheism within the theological system. On the other hand, a manifest hierarchical conception of the divinity goes along with egalitarian politics in human society. The conception of a relational equality, derived from the idea that people are equal in their relations with the divinity, is effectively present alongside an ideology of substantial egalitarianism among human beings. 
Clearly, in the former model there are mediators between humans and God, the Sufi and Bektashi master (murshid), for instance, or a priest or sacrificer, acting as representatives of the secular congregation, who place themselves on a higher plane than the latter but in a position of inferiority with respect to the deity. In contrast, the mediational structure of the latter model is necessarily of another type, and claim to be the negation of hierarchy of any sort. The initiative must be entirely in the hands of the divinity, which may manifest itself in a number of hierarchised emanations but without any mediation, by dispensing the gifts of its grace on the faithful, with believers receiving direct, immediate inspiration. Charisma, divine grace, and spiritual knowledge touch them without the help of any intermediary, and is in no way affected by the more or less effectiveness of any ritual or specific expertise, performed or controlled by a mediating priest or murshid.

Viewed from this angle, as I showed elsewhere, ${ }^{23}$ the system of beliefs and practices related to Bektashism would be a kind of liberation theology, which makes it possible to meet social, cultural and national perspectives, insofar the murshid is perceived as "God himself in a different guise". In turn, when the murshid will be perceived as a kind of priest, "intermediary between the talib and God", Bektashism would be an orthodox ideology aiming at the establishment of political hierarchy in society.

At some point, like in early Sufism, for the masters of the Ways the mystical tendency becomes highly dangerous as an individual experience, since there can be mystic Ways, the Sufi argument goes, to other gods than God. Hence the necessity of guidance under an experienced director was insisted on. The potential for perfection is present in every human being, since God is present in everyone. However, in order to go through the Gateways of spiritual growth and to experience the divine Reality and ultimate Truth (hakikat) and penetrate to their inner significance, ${ }^{24}$ one needs a guide, a spiritual master, the murshid, who had himself reached the perfection stage of the Perfect Man (insan-i kamil), ${ }^{25}$ and is thereby entitled to great veneration. ${ }^{26}$

The normal relationship of a talib to his murshid has often been described as a spiritual sonship, but the relationship implied by these terms in different stages of development came to be entirely different. On the account of Bektashi beginnings in thirteenth and fourteenth centuries and during times of persecution, it is generally assumed that the continual masters' guidance of individual disciples has made them appear quite naturally as the medium between God and humans. However, the overriding importance of the system of murshid-talib relationship, which became the very foundation of the Sufi orders, implies a shift in morality which must correspond to the radical change that took place in Bektashi environment after the organization of the order in sixteenth century and which may also be discerned each time after recovering from periods of persecution. ${ }^{27}$

The organization of what cannot be properly organized - personal mystical life - arose naturally through the need for guidance and association with kindred aspirants. But through the mysticism transformed into cult, the individual creative freedom of the follower was fettered and subjected to conformity and collective experience. Under the earlier masters guidance had not compromised the spiritual liberty of the seeker, but with the institutionalization of the murshid-talib hierarchy, subjection to the arbitrary will of the perfects turned him or her into a spiritual slave, and not of God, but of a human being, albeit one of God's elect.

Religious scholars normally outline three successive stages of development in Sufism: asceticism (zuhd) to mysticism (tasavouf) and then to corporatism (tarikat). 
Trimingham characterized these three stages, respectively, as the individual's surrendering to God, his or her surrendering to a rule, and finally his or her surrendering to a person. ${ }^{28}$ In the first stage, the master and his circle of pupils were frequently itinerant, having minimum regulations for living a common life, leading to the formation of undifferentiated, unspecialized lodges and convents. Methods of contemplation and exercises for the inducement of ecstasy were individualistic and communal. In the second stage the transmission of a doctrine, a rule and method corresponded to new types of collectivistic methods for inducing ecstasy. Deriving from professed illuminates, the development of continuative teaching schools of mysticism (silsila-tarikat) disciplined the mystical spirit within organized Sufism and made it conform to the standards of tradition and legalism. In the third stage the introduction and transmission of allegiance toward the doctrine and the rule formed new foundations for numerous 'corporations' or 'orders', whose practices were fully incorporated with the saint veneration cult.

Essentially, as time went on, the organizational system of the Bektashi Order was increasingly replaced by another one, more sophisticated and much more institutional, ecclesiastical and hierarchical. Of course, even in the heydays of Bektashism, the distinction between talibs and murshids was maintained, but the subordination of the former to the latter was emphasised. In addition, both categories simply became the last two ranks of a larger hierarchy containing a number of other additional grades, so that the system of two classes was replaced by a much more complex one.

Finally, all available accounts in the literature clearly show that under the specific conditions of Ottoman patronage during sixteenth and eighteenth centuries, once again reiterated in Independent Albania, the internal organisation of Bektashism developed into a centralised ecclesiastic hierarchy. The hierarchically lower level, the class of ordinary people and potential followers was categorized as adepts (muhibs). The immediately superior class included the elect (eren or të mbërrimët), righteous and truly initiated. ${ }^{29}$ They may become dervishes and later 'fathers' $(b a b a)$, religious leaders hierarchically recognized. The organisation as a whole is now headed by a single leader, the grand-dede or kryegjysh (literally "head-grandfather"), who is supported by leading figures known as khalifa.

Centralization was pushed to the extreme, as the Arch-grandfather, legitimate heir and terrestrial representative of God, came to act as the supreme pontiff of the holy religion of the Order. High priest and master of the masters, Grandfather of all Fathers and Grandfathers, he embodied all of the spiritual power and was supposed to lead and govern his followers by ensuring that the dogmas were maintained and transmitted properly, discipline and tradition were respected, and orthodoxy was upheld.

Out of the diverse heritages of Turkic pre-Islamic and Christian superstitions and heterodox tendencies, the nebulous Bektashi order became a hierarchical institution, highly organised and centralised, especially after it became linked to the powerful military body of the Janissaries. Even though in contrast with the ulema there were no class distinctions among dervish groups, Bektashi leaders formed an instituted religious class. The officials of the order approached the role of a clergy class similar to that in Sunni Islam or Iranian Shiism, and the tekke provided a parochial village religion, with a system of hierarchically affiliated lodges, which in many respects was equivalent to the diocesan church system.

As in early Sufism, a change took place with the development of collegium pietatis into a collegium initiati whose members ascribed themselves to their initiator 
and his spiritual ancestry, and were prepared to follow his Way and transmit it to future generations. The leading murshid even ceased to teach directly, and delegated authority both to teach and initiate to representatives (khalifa). A special cult therefore surrounded the murshid, associated with the power thought to emanate from the founder-saint of the order. He became the spiritual heir of the founder, whose qualities and powers become inherent in him upon his succession. The Bektashi life of recollection and meditation now became increasingly associated with a line of ascription, which bestowed the order, its formulae and symbols, as emanating from the master and guiding all disciples along his Way in his name, while the new aura emanated from the murshid as a protégé (wali) of God probably came to imply the belief in his role as a mediator and as an intercessory with God.

The theological rationalisation of the necessary relationship between talib and murshid was articulated through the historical aspect of the divine hierarchical chain (silsila), an idea which was available already in the very theological conceptions of Sufism. On first sight, as Trix showed, divine and historical chains connecting the murshid to God, in Bektashism may be seen as a device to legitimise the place of the murshid cosmologically. ${ }^{30}$ Yet, given the excessive proliferation of Orders and their ramifications in almost any local setting - as it can be shown in Albanian context ${ }^{31}$ - there is good reason to believe that the primary concern of the founders and leaders of an order's branch, while seeking to gain personal ascendancy and protect themselves against accusations of doctrinal irregularities, as for instance in the case of the Sanusi, ${ }^{32}$ was that of demonstrating their orthodoxy by showing how their teachings followed those of some famous theologian whose orthodoxy was acknowledged by all. They could then use the authority of this master and all intermediary and transmissive links right back to the first Caliphs and the Prophet himself for their teaching and practice. Thus, the silsila became a means to assert the new doctrinal orthodoxy of the order. As new ideas were fostered on eminent Sufis of the past in order to make these ideas respectable, the silsila provided a doctrinal as well as a power line leading to the ultimate source of religion.

In this way, the orders developed their final forms of organisation and spiritual practices. Innovations were fully integrated and their spirit and aims were stereotyped. No further development was possible and new revelations of mystical insight that could mark a new point of departure in either doctrine or practice were precluded. The authoritarian principle had become the chief feature of the organization, along with the veneration of the master, the supreme inheritor of the divine mystical wisdom, and subjection to his authority was unconditioned. The organisation was hierarchical, imposing uniformity, and instituting an elaborate initiation ceremony and disciplinary practices, such as solitude, fasting, and other austerities for adepts.

Religions then experience three phases in their evolution, which correspond to what Joachim Wach has called the threefold expression of the experience of the sacred. ${ }^{33}$ First of all, doctrinal elaboration, based on prophetism, gradually fashions revelation into an oral message, which receives a written codification, becoming a theology and a dogma. Next, the worship shapes behaviour into a liturgy, rites, a protocol, whose performance is usually entrusted to ministers of the cult who become its guardians and make sure the rules are not overstepped. Last, in reaction to the anarchist tendencies of frenetic movements or ataraxy, organizational measures are taken by the creation of a hierarchy determining roles, classing believers, and controlling the tradition. Its task is to coordinate and 
subordinate, canonise and censure, balancing the measures of tradition and innovation, and presiding over the relations between the religious body and its environment. At this point, a religious institution, i.e. the 'Church', is established. It takes its place within a religious society by means of which human society asserts both its convictions and its doubts.

However, both sociological conceptions of the role of religious faith, orthodoxy and liberation, are not, by any means, mutually exclusive or essentially contradictory. There are not two kinds of behaviour set once and forever, nor is there a merely 'routinisation' in a Weberian sense, ${ }^{34}$ but rather a process of dialectic change and transformation. As political conditions change and the organization of religious structures undergo a number of transformations, the essential differences between hierarchical and unified types of theology, acting as mediating cultural systems of representation between humans and God, change and adapt accordingly.

If the character of Bektashism and all Sufi groupings of Islam showed first a cultural system corresponding to the model of religious mediation in which all hierarchies are denied, when the members of the previously persecuted religious minority have already acquired a degree of religious and political respectability within society at large, the subjective and millenarian doctrines of heterodoxy and liberation theology fade into the background. In the end, the chances are that the heirs of mystics and the heterodox promoters of spiritual reform and social movement will turn into followers and faithful defenders of a legitimate authority. They will become the spokespeople for an institutionalized orthodoxy whose support will be sought by the political regime.

\section{Instrumental Politics}

The transition from innovation to conservatism in theological conceptions and organizational structures, and the subsequent renewal of innovation in support of either liberating social and national movements or in the re-establishment of a new political power in society, takes on different forms and tones, forming a complex process requiring detailed historical and anthropological analysis of the cultural values and social entities involved. Instrumental transformations of this kind are clearly evidenced by the development of Bektashism down its history, depending on different political contexts and the course of events, as much in the classic Ottoman period, in the reformed Ottoman system or in Modern Turkey. A considerable number of studies have shown how issues of Bektashi or Alevi heterodoxy have been often politicised and ethnicised. ${ }^{35}$ Less known are perhaps the transformations amongst Albanian Bektashis.

It can be said that in Albania Bektashism arrived at its highpoint in striking similarity with its Ottoman and Modern Turkish heydays. Already during Ottoman period, Bektashis in Albania and in southern parts of former Yugoslavia benefited from political hegemony and many Christian sanctuaries fell into their hands. The growth of Bektashism in Albania seems to have profited especially under the political patronage of Ali Pasha of Tepelena, the powerful quasiindependent governor of Yoannina from 1788 to 1822.

During this time the Bektashis must have developed close links with the secessionist efforts of Ali Pasha, who had entered into dispute with Ottoman central authority in order to gain recognition for an autonomous administrative entity. Following the example set by his contemporary and fellow-countryman 
Mohammed-Ali Pasha in Egypt, Ali Pasha had gained considerable success in establishing and strengthening a local administration that had recognised his authority in Thessaly and in southern and central Albania, where he ruled with a degree of complete independence. In this context, Bektashi leaders benefited of new opportunities and the order enlarged its following considerably, to such an extent as Ali Pasha is considered to be 'responsible for the propagation of Bektashism', because of the support he gave to its propagandists. ${ }^{36}$

The emphasis on the relationship between the Bektashis and Ali Pasha is clearly related to political considerations. Ali Pasha embraced and supported Bektashism because of its growing ideological and organisational potential in being instrumental for backing his own general policy. Bektashi dervishes are said to have served him as diplomatic agents, and he used their organisation and religious doctrine to win popular support and occupy new territories, to increase his power, widen his political influence, and consolidate his independence from the central Ottoman authorities. By embracing Bektashism and giving his support to the spread of the order which called for Shiite revenge against Sunni powers, he was able to engage in a conflict, both political and religious, against Ottoman dominance.

Modern area specialists, however, notice but do not explain the facts, while others, who suddenly seem to be interested in analytical approach, undoubtedly imbued with the general development of a theoretical and ideological interest in nationalism which has put instrumental ethnicity far in the forefront, may go on as to quite misunderstand the politics of religion. A case in point is Nathalie Clayer who tends to deny the historical evidence and claims that the political-religious connection of Ali Pasha and the Bektashis is only a myth created much more lately and perpetuated in the enthusiastic intellectual circles of Albanian Bektashi and nationalist leaders, relayed by the tradition of intellectual scholarship. ${ }^{37}$ Many myths were clearly aimed at forming an Albanian national identity associated to the Bektashi religious identity according to Bektashi politics. Yet, what is lacking here is a further analytical imagination to see that such myths and the ideology they convey do not contradict by any means the historical evidence of real politics. On the contrary, as it happened at the time of Ali Pasha, real politics and ideological myths seem both to be transformations of the same instrumental pattern of religious politics.

Ali Pasha is indeed said to have spread the Bektashi "heresy" among the Albanian Muslims with the aim of dividing Albanians from Turks and creating the first national Albanian state. Clearly, Bektashism is never boldly claimed as the potential power to create an independent 'Albanian identity' and an independent 'Albanian State', but the impact of a figure like Ali Pasha is due to the fact that he could more concretely embody a 'local resistance against central authority' through his polity and the large autonomy which he managed to acquire. The historically grounded position of the Bektashis in contesting the central Sunni authorities, as a religious group professing a heterodox Islam, naturally opposed them to the Sunni-based policy of the Ottoman authority. Subsequently, it seemed natural to transform this religious opposition into a cultural-religious opposition and later to a political-religious opposition.

Indeed, after the defeat of Ali Pasha in 1822, followed a few years later in 1826 by the persecution of the Bektashi order in the whole Ottoman Empire, a ruthless purge of the Bektashis was undertaken, in Albania as elsewhere, which might have compelled them to find themselves in opposition. Henceforth, they will 
embark on a prolonged resistance to Ottoman power. Later again, the political position of the Bektashis is particularly revealing. During the difficult history of assertion of the Albanian national identity in the late nineteenth century, a great number of Albanian Muslims, despite their 'divided loyalty', ${ }^{38}$ often firmly expressed the will to sever links with the Ottoman Empire. ${ }^{39}$ The well-known heterodoxy and tendency to assimilate external elements enabled Bektashism to fully integrate nationalism in its doctrine and made it extraordinarily popular in Albania.

The Bektashi's traditionally difficult relationships with the religious and political Ottoman authorities certainly contributed to their choice of anti-Turk and nationalist stance, ${ }^{40}$ but this went along with a reinforcement of liberation heterodoxy characteristic of their system of beliefs and practices. It is certainly not surprising that it was Naim Frashëri - the well-known Albanian poet and activist of national movement in the nineteenth-century, who was striving to establish a unified written Albanian language and glorify the Albanian past in a literature of his own - that explained and to some extent founded, in his Bektashi Pages (1896) ${ }^{41}$ the novel theological and practical principles of Bektashism and the organisational rules governing its functioning.

The matter is especially interesting for its entire freedom from any fanaticism, dogmatism and mystification, and its insistence on ethics. ${ }^{42}$ Under the direct influence of Naim Frashëri's intellectual speculations, the development of Albanian Bektashism showed, much more than any other Sufi order or other Bektashis elsewhere, that esoteric knowledge was not a privilege exclusive to a particular genealogical lineage but acquired by spiritual progression, thanks to a divine grace freely and directly bestowed, in close relationship with the expression of Albanian national sentiments and the inculcation of patriotism as the highest of virtues.

However, I believe it is an exaggeration to claim that Naim Frashëri's attempt has been to bridge the religious divide of Albanians by proposing to turn Bektashism into an all-encompassing national religion for all Albanians. ${ }^{43}$ Earlier accounts in the literature have suggested that Naim Frashëri's attempts were aimed simply at giving the Bektashis a somehow Albanian character. ${ }^{44}$ I have argued elsewhere that it is the active promotion of its dualist character and pantheist conceptions that might have reasonably made it possible for Bektashism to join with Albanian national ideology. ${ }^{45}$ Already in early sixteenth century and probably in much the same vein, the ideological basis of the Iranian dynasty exposed to the hostility of Ottoman power was rooted in the political promotion of mystic extremist Shiism and messianic Turkic beliefs drawn from those Kizilbash elements which would subsequently become the essential constituent parts of Bektashism.

Naim Frashëri was not a unique leader, but the quality of his verse together with his other nationalist and educational activities placed him at the forefront of the avant-garde of Albanian national movement. He became defender of Bektashism not merely because of any personal special link or conviction but by means of Bektashism he could better proclaim his contest credo in opposition to Ottoman occupation. As long as the Ottoman political power coincided in ideological level to Islamic religion, all deviation from dogmatic and orthodox Islam was assumed to take on a political meaning of opposition. By the same token, by voluntarily putting forward and even downrightly developing this very character, he aimed to bring Bektashism closer to his own theory of nationalism. 
To this extent, Albanian nationalism and the construction of the Albanian nation could not be, by any means, an offspring emanating exclusively from Bektashism, as some specialists in the area, probably limited by the narrow contours of the very object of their studies, have hastily and uncritically claimed. ${ }^{46}$ Of course, Abdyl Frashëri, elder brother of the poet and prominent leading member of the League of Prizren (1878-1881) which was the crucial episode toward Albanian independence, belonged to the Bektashis. It is also a generally held opinion that the Bektashis played a significant role in the movement of 'national awakening' (Rilindja) in Albania from 1878 onwards.

This might be, however, another instance of the instrumental myths surrounding the Bektashis, for it is well known from other sources that most of the Bektashi tekkes in Albania were founded at the turn of the twentieth century, when a renaissance of the order took place rather as a result of the national movement. It is above all since the last decade of nineteenth century that the Bektashis actually started to be very active in the development of both cultural and national movement in south and central Albania, which must have paved the way for the introduction of elements of nationalist ideology into their religious doctrine. It seems reasonable therefore to consider that it is the new Albanian Bektashism, especially after the influential elaboration of its heretical doctrines instilled by Naim Frashëri, that might have become the offspring of Albanian national movement much in the same way as Kizilbash ideology once became the instrument of Safavid policy against Ottoman power in early sixteenth century. In turn, Bektashism has been often idealized as one of embodiments of the Albanian Volksgeist, which Bektashi leaders must have exploited later in a deliberate instrumental politics to make Bektashi ideas attractive among non-Bektashis who could swell the ranks of the Order while contributing to the creation of an autonomous and, later, independent or even communist Albania.

That is why the continuous emphasis on the historical connection of the Bektashis with Ali Pasha proved to be still instrumentally effective, for the large autonomy that he gained, or the prefiguration of a first Albanian national State that he was supposed to have founded, corresponded to the aims or ideals of the Bektashi leaders at the time of the Albanian national mobilization. Much more, in the process of creating a national history from the viewpoint of the Bektashis, Ali Pasha came to be presented as the second hero of the nation, after Skanderbeg, while both came to be presented as belonging to the Bektashi order. Having been educated in the Sultan's court, Skanderbeg was related to the Janissary corps and therefore believed to have been a Bektashi. One of the prominent Albanian Bektashi leaders, Baba Ali Tomorri in his History of the Bektashis, ${ }^{47}$ makes the fight of Skanderbeg a part of the first struggle of the Bektashis against the Ottoman Sultans.

Such myths were all the more instrumental as the proto-national character generally attributed to both Skanderbeg's and Ali Pasha's polities, and the necessity to stress the former's Christian character or to diminish the latter's Muslim character, corresponded to the strong denigration of Islam in the laicizing framework of the independent Albanian state, while the image of the Bektashis remained a liberal and nationalist one. That is perhaps the same reason that, later, both King Zog and Enver Hoxha will be sometimes believed to be of Bektashi origin. ${ }^{48}$ In such a way the Bektashis will reassert their contribution to the construction of the Albanian nation and anticipate political benefit.

Whether religious politics was instrumental in mobilizing ideological myths or actual action, on the eve of the Albanian independence, the Bektashis were 
numerically important and politically influential. It was under the political patronage of independent Albania, however, that Albanian Bektashism, recognised by the highest governmental authorities as an established denomination, came to be a nationally and internationally structured ecclesiastic institution. The Bektashis had an institutionally recognised representative in the highest function of the State. The High Council of the Regency of independent Albania was composed of four rather than three members, representing each of the country's denominations: Sunni Muslims, Orthodox Christians, Catholics, and Bektashis. In this way, Albanian Bektashis ceased to be considered as conventional members of Islam, and rather, were regarded as an independent religious congregation.

This political evolution of Bektashism in Albania was run in parallel with another development in matters of organization. After the independence of Albania in 1912, ties with the Bektashi world centre in Anatolia, and the order's hierarchy in Turkey were slowly cut down. Another reason was the general dismissal of dervish orders in modern Turkey and their definitive abolition in 1925. Recognised by the new Albanian State as one of the accepted religions of the country, the Bektashis continued their activities independently in Albania in conformity to a printed set of regulations approved by the Albanian government. It is hardly surprising that from that time onwards the Albanian Bektashis took steps to establish in Tirana the order's world centre. Finally, with the initiative of the order's head Salih Niyazi Dede, in his capacity of Arch-grandfather and supreme pontiff of all the Bektashis, the seat of the Order, formerly in the central tekke at Hacibektash Village in Anatolia, was actually transferred in a purpose-built head-tekke in Tirana, the capital of Albania. In 1930 he was appointed to that position by the newly crowned King of Albania.

Already, the Bektashis obeyed to a rigorous and severe rank of hierarchy and the whole system of tekkes was hierarchically ranked in relation to each other, ${ }^{49}$ which militated to increasingly concentrate rich endowment of estates. Because of the explicit political circumstances in the reality of independent Albania, the organisation of the Order became increasingly structured, improving its methods of recruitment of followers and the appointment of its hierarchy, especially in matters of celibacy and non-hereditary offices. Albanian Bektashism actually adopted a hierarchical organization in which the rank held by a member was graded and his status conformed to his seniority and the proportion and degree of his commitment and loyalty.

As specialists show through abundant documentary evidence, ${ }^{50}$ the hierarchical pattern of the organisational structure of Bektashism in Albania reached a very peculiar expression not only in terminological, local terms, but also in a more sophisticated and clear-cut ecclesiastical as well as political hierarchy, which perhaps surpassed limits observed in Ottoman context. Between 1921 and 1950 the Albanian Bektashis organized five congresses to accomplish the change of an Ottoman dervish order towards a religious congregation of the new Albanian Nation. According to the 1950 statute of Albanian Bektashis, the order must also serve as an umbrella organization for other Sufi communities in the country.

Certainly, this final stage of the hierarchical and centralised organisation coincided not only with the establishment of religious and political power but also with tightening of state control over religious matters. Actually, the political regime sought every time the support of instituted Bektashism as that of other religious denominations, and even took the initiative of imposing and controlling 
their doctrinal orthodoxy and hierarchical organisation. All kind of intimidations were used to this end, and it is by no means a mere coincidence that every time that a new regime came to power in Albania the highest level of Bektashi hierarchy suffered internal cabinet reshuffles, even leading to repeatedly mysterious murders.

The Bektashis claim, for instance, that Arch-grandfather Salih Niyazi Dede was murdered in 1941 by the Italian fascist regime of occupation because he didn't accept collaboration. Later, after the advent of the communists in power, while the statute of 1945 showed clear opposition against Communist leadership, internal strife within the community escalated in March 1947 when Arch-grandfather Abaz Hilmi shot dead killing his two assistants Baba Faja Martaneshi and Fejzo Dervishi. Because they were loyal towards the Communist regime, it is believed they had demanded the order to collaborate more closely with the communists while accusing the Arch-grandfather of being a reactionary. Not surprisingly current Bektashi leaders will again present a different version which must fit better to modern structuring tendencies of the order. According to Baba "Mondi" from the Arch-grandfather's See in Tirana, Baba Faja Martaneshi was killed because he had violated the rules of the Bektashi order by being married and having a son! This version is of course questioned by others who claim that Baba Faja Martaneshi died under very suspicious circumstances, with Enver Hoxha himself being suspected to have ordered his assassination. After this incident, however, the Arch-grandfather was forced to commit suicide, and repression against non-loyal Bektashi members started. The order was totally put under government control with Ahmed Myftar Dede, a loyal follower of Communist doctrines, appointed as Arch-grandfather and staying in office until 1958. ${ }^{51}$

In fact, apart from the dangers of religious leaders revolting against established authority, which could only be successful under special conditions, there is always the possibility of their direct intervention in state affairs. Consequently the political authorities, well aware of their potentialities rooted as they are in the lives of the masses, often seek to control, regulate, and conciliate them rather than to suppress them. The Albanian communist regime, like the Ottoman government in the past and not unlike the energetic Ali Pasha in his time, was able to deal with almost all religious groups by playing off the more influential against each other.

Finally, with the increasing power of communist ideology in Albania, all religions - eliminated in 1967 - were rendered purely and simply unnecessary. These trials and tribulations, in turn, created new conditions for Albanian Bektashism to become once again the religion of victims of persecution. The Bektashis in Egypt and Turkey, constituting a clandestine movement, declared their independence from the Albanian world centre and elected in 1949 Ahmed Sirri Baba as head of the order in the tekke of Cairo. Likewise, in Michigan, where Frances Trix also found her master, Baba Rexhebi founded the Bektashi tekke of Detroit in 1954. But once again after the downfall of communism in the 1990s in Albania, Bektashism re-emerged in its full great pomp by establishing the new Arch-grandfather Haxhi Dede Reshat Bardhi in the purpose-built Holy See of Tirana.

However, the Bektashis are still trying to redefine themselves politically in the limited space left to them by Sunni Muslims. Their main aspiration is to maintain public recognition of their Order as 'the fourth religion' in Albania, i.e. as a traditional denomination with official status in the State. For this purpose they developed a close relationship with the newly formed government of President 
Berisha's democratic party (1992-1997), taking part in his political campaigns, despite the vagaries of political changes when the coming to power of socialist opposition's government (1997-2005) might have made their policy temporarily counterproductive.

Currently, the Albanian Bektashis have an ambiguous status which places them somewhere in the middle between the three official religions and the other religious minorities. Similar to the Sunni Muslims, the Orthodox Christians and the Catholics, the state recognizes their existence de facto. Their spiritual leader participates in all state ceremonies, and recently the Nevruz holiday on March 22 was declared to be an official holiday, because it coincides with the Day of Democracy. They have, however, no right to have their own representative in the State Secretariat of religions and all their activities are placed under the supervision of the Sunni Association.

\section{Toward Orthodox Ideology}

From almost all documentary accounts the important fact can be shown that Bektashi conceptions, particularly at the critical periods of Kizilbash movements in Ottoman Anatolia, Alevi movements in Modern Turkey or national movement in Albania, appear extremely heterodox and heretical. However, especially in its Ottoman heydays, maintaining a strong central organisation, Bektashism even claimed to be a Sunni order, ${ }^{52}$ in spite of its very unorthodox and Shiite tendencies.

Many discursive interactions in Bektashi narratives, poetry, and adages actually show a coherence of linkages progressing from the outer to inward, that is, as Frances Trix pointed out, ${ }^{53}$ from a more Sunni or orthodox Islam to the decidedly mystic Sufi conceptions, apparently because Sufism or Islamic mysticism could only progress from the outer Sunni form to an inner Sufi meaning. When the Bektashis do affirm, for example, the importance of Sunni injunction to rituals, fasting and pilgrimage, they understand true rituals of namaz not as mere superficial practice but rather esoteric symbols of justice and goodness, giving emphasis to sincerity of faith and not to the religion's outward observances. They take true fast of Ramadan not as exempt of material food but rather a spiritual cleaning of heart from the evil, as they take true pilgrimage not a physical journey to Mecca but rather a spiritual journey to the heart. The Bektashi world of discourse can be seen then as a legitimizing strategy in which a later relationship not sanctioned by Orthodox Islam, seeks legitimacy by being related to one of the basic relationships of Islam. In the same way, the order of describing the hierarchical chains in which the Bektashi conception of divinity is structured parallels again the outer to inward paradigms from the more general Sufi to the more particular Bektashi.

A change towards greater systematization is seen in the manuals being produced as guides for initiation, which became particularly important for understanding the theological significance and the social experience of Bektashi religiosity. Whilst the earliest manuals of this nature could be found amongst Sufi orders as far back as toward the eleventh century, the most popular are found very late, especially during eighteenth and nineteenth centuries. From Albanian Bektashis two seventeenth-century manuscripts written in Turkish are known, in which it is interesting to notice how the language, in contrast with both earlier and later manuals, is wrapped in the flowery Sunni orthodox vocabulary, often ambiguous, but appearing sometimes as a forced disguise to all outward appearances of Sunni orthodoxy. ${ }^{54}$ 
It can be showed that in these texts there is an effort to comply with the dogma of orthodox Sunni Islam to cover features of a categorically Sufi and Shiite nature. I believe the explanation of this attitude is to be found in the context of a more hierarchical development of the Bektashi internal organization, in connection with the historical and political conditions of Albania in the period of the texts' composition. In seventeenth century, as political power in the Ottoman world was overwhelmingly in the hands of orthodox Muslims, Sunni images were the grounds of legitimacy. Moreover, even though Sunni Islam was often a cloak covering the essential Shiite and pantheistic character of the Bektashi faith, and that the general opinion assumes that the Bektashis entirely neglect the religious performances required by the Sharia, the simple discussion of the Sharia Gateway to religious knowledge is an indication of the part Sunni Islam played in Bektashi life and thought.

The fact that the Bektashis were rarely attacked on grounds of doctrine or innovations is directly related to their association with the Janissaries and the Ottoman authority. In turn, the officials of the order clearly handed over their loyalty to the Sunna of the Prophet as a necessary stage in their code of discipline. In fact, every time the order approached the establishment of orthodox political powers, whether in Ottoman as in Modern Turkey or in independent Albania, its hierarchical and centralised organization also corresponded to a doctrinal radicalism. In these conditions, the mystical content of the order weakened. Bektashi leaders were seeking to subject the mystical element to Islamic standards, to make mysticism innocuous by tolerating much of its outer aspects and forms in return for submission.

It is by no means accidental that the sources emphasise over and over again that a certain eminent Bektashi took the Sharia seriously, proving that as long as the desire for power of the orthodox postulates its own position as absolute, the educational attitudes of the Bektashi order will necessarily follow suit. Order leaders vied with one another in demonstrating their loyalty and subservience to legalistic Islam, and in the process Bektashism were emptied of its essential elements and left with the empty husks of mystical terminology, disciplines, and exercises.

More importantly, as generally within institutional Sufism, from the moment the religious Bektashis leaders felt the need to support their statements with prophetic sayings, they also felt it necessary to express conformity with the Sharia, the revealed Law of orthodox Islam, which coincided with their growing conformity to the legal establishment. Bektashi leaders increasingly strive in reprimanding several colorations of mysticism and fanaticism, trying to bring followers back to more respect for fundamental Islamic rules. They vigorously reject criticism that the Order and its doctrines are against the beliefs of Islam and that Bektashi dervishes make only prejudice to Islam, hiving themselves off from the genuine Islamic teachings.

Religious scholars, in particular, warn against the belief in the incarnation of God in human form, the transcendental annulment in God, and the cult mysticism mistaking the murshid for God. They try to defend Bektashism from all accusations of heterodoxy or liberalism and consider it identical with the normal understandings of legalist Sunni Islam, stressing its missionary role and transmissory links militating against doctrinal deviations of any kind. While marginal heterodox and nonconformist influences are admitted, it is claimed that Bektashism might have been 'misused and misunderstood by destabilizing forces and currents hostile to Islam society during nineteenth century', which did cause its disgrace in 1826 . And 
the argument goes that 'the Order that had enjoyed the full support of Ottoman power until that time cannot be thought outside the fundamental values of Islam'. Henceforth, the spiritual way of tarikat must necessarily go through the legal gate of the Sharia. ${ }^{55}$

That is why, in Bektashi circles, Haji Bektash is increasingly presented as a good Muslim, respectful of the prescripts of Islam, and according to a late tradition, even as a descendant of the Prophet. ${ }^{56}$ Especially in the period of independent Albania, representatives of the hierarchy of Albanian Bektashi clergy reacted against assertions that often tended to consider the order of Bektashis as a doctrine of strong heterodoxy, diverging from orthodox Sunni Islam much more than other Muslim orders. Not surprisingly, they kept up a certain appearance of respect for the law of Sharia. Birge, for example, witnessed that several evenings as he sat in the guest-room of the head of the Bektashi Order in Albania, he saw outside the window a dervish stepping on to the veranda and giving the evening call to prayer. When, in surprise, he asked the reason for this he was told that this was the Sharia part. ${ }^{57}$

In Bektashism as in certain other dervish orders, the cult of Ali, carried to an extreme, was a major cause of friction. The cult of Ali in the dervish orders was exaggerated to a degree intolerable to the orthodox mind, especially since, in extreme cases, it culminated in his deification, or in any case, in a veneration detrimental to that of the Prophet. For orthodox Islam, Muhammad and Ali are human beings and they cannot be of divine essence, much the same as for the doctrine of Trinity in Catholic orthodoxy there cannot be any hierarchical projection within a divine essence. Therefore, as Christian heresy pursue a doctrine of Docetism that refuses Trinity and denies the fusion of the divinity and of human nature as inseparably united and fully achieved in the person of Christ, the divine identity of Muhammad and Ali, quite common to Bektashis, is a very extremist and heretic Shiite concept.

However, in one of his treatises on Bektashism, Baba Rexhebi makes a clear distinction between them. Furthermore, he once again maintained that the order respects the rituals of faith and insisted that Bektashi rituals are not in opposition to Sunni Islam, that Bektashism is 'within Islam' and, sometimes, that it is even the 'real' Islam. ${ }^{58}$ Allegations of this kind, fervently claimed by religious scholars, ${ }^{59}$ or naively justified by seemingly well-intentioned local scholars, ${ }^{60}$ may well be noticed by area specialists, ${ }^{61}$ but without necessarily explaining - nor indeed understanding at all - that a deep evolution had been already achieved, not only in organizational and political structures, but also in theological and religious conceptions.

When during the Communist period, Baba Rexhebi escaped to the United States where he founded the Bektashi tekke of Detroit, he came in contact with more sophisticated types of Sufism, read in English the works of Western Orientalists, specifically French Orientalist Henry Corbin, ${ }^{62}$ and understood that to survive Bektashism would need to go through a drastic revision. In his theological treatise he tried to put Bektashism in the perspective of Muslim mysticism and relate it to other more elaborate forms of Sufism. In particular, he demonstrated that Bektashism is closely related to Iranian Shiism, and he tried to dismiss the shamanistic and pre-Islamic influences in order to bring Bektashism back onto the path of Shiite orthodoxy. As this book is the only one of its kind available in the Albanian language, his work had a tremendous influence on Bektashis, even though the doctrines found in it differ greatly from the Bektashi traditions. More importantly, his book opened the door to Iranian influence. 
Iranians, like Saudi Arabians, came in Albania after the fall of Communism in the 1990s with impressive budget and are now the most active of Islamic missionaries who have succeeded in rallying a number of intellectuals, especially of the older generation. Not surprisingly, they are more successful in recruiting members of the former Communist Party than independent intellectuals. Apparently those who had put their faith in Communism feel a great vacuum of power opportunities when the ideology was discredited. Indeed, not only they are more open to look for another ideology to replace the old one, but they are also motivated by more worldly reasons such as large salaries paid by Iran and other Muslim countries and many business opportunities with foreign investors. In turn, Muslim propagandists have succeeded in creating somehow a nucleus of Albanian Muslims sharing their strict view of orthodox Islam, which remains nevertheless a partial success limited to some urban settings only, for the bulk of rural population is quite resistant to this version of Islam.

Although Bektashis are not orthodox Shiites, Iran is very active in supporting them. A good example of promoting Iranian political and diplomatic objectives is the creation of the influential Saadi Shirazi Foundation. While in practice, the foundation is part of the Iranian Embassy and is believed to be a cover for the Iranian secret services, the official purpose is to promote Persian culture and Islamic values. The single aim of the impressive translation and publication programmes and other research and cultural activities is to link Albanian Islamic culture to Iran. Under the pretext of reviving the great Islamic culture that Albania has inherited', Iranians finance all sorts of historical and sociological research aimed at demonstrating that Albania is part of the Islamic world. In a way, this policy helps to revive the particular Ottoman and Oriental legacy in Albania. Cultural production of this kind is mostly ideological, aimed among other things at showing that Albanian nationalism and Islam go together insofar as their nationalist ideology is believed to be grounded in the Bektashi and other tolerant traditions of progressivist Islam.

In turn, such a mystification allows Iranians to seize the opportunity of bringing the Bektashis back to the Shiite flock and hardening the orthodox line of Bektashism. A significant number of new Albanian Bektashi dervishes are also sent to Iran at the Theological Faculty of the Holy City of Qom for religious training. It is probable that when they return to Albania they will be much closer to Iranian Shiism than Bektashism ever was.

Once again specialists may touch upon these recent conflictual developments within Bektashism. After the $6^{\text {th }}$ Congress of the Albanian Bektashis in Tirana, for instance, growing opposition is noticed among the remaining Bektashis in Macedonia and Kosova as well as immigrant Bektashi communities in Western Europe and overseas against Arch-grandfather Reshat Bardhi in Tirana. ${ }^{63}$ Yet, quite simplistically, they cannot see other explanation than a supposed weakness of the current leader of the Bektashis, who unlike his energetic predecessors, seems to be only "an old man with little education" who "lacks the vision necessary for the movement's survival". ${ }^{64}$

\section{Concluding remarks}

The establishment of dervish orders can be considered as the organized form of mysticism, and the psychological affinity between mysticism and pantheism, related as much to dualist and gnostic conceptions as to the Shiite devotion to Ali 
has been pointed out. This is doubtless justified, but at the very moment that it begins to organise and systematise, it must whether split into different sects or begin to create a new separate orthodoxy of its own. ${ }^{65}$ The moment of crisis would have come at that point, for mysticism does not allow itself to be pressed into a system originating in rational considerations. The contrast of any mysticism to its own orthodoxy, as far as it exists, as it does in this case, lies in the fact that mysticism is always based on a feeling of pantheistic wholeness, while any monotheism is the result of intellectual thought. The all-embracing sentiment relies on itself, while monotheism and any theism are the result of a search for the respective causes. The development of orthodoxy is aimed precisely to overcome these irreconcilable differences.

Basically, translated in sociological terms, this means that the rigid, intolerant and authoritarian attitudes of the local religious dignitaries, as well as the formalism and dogmatism prevailing in all fields, religious or political, simply express the haunting fear that they will lose their power. Within the political system, as Levtzion has argued for other contexts, ${ }^{66}$ Islam and religious ideology are by no means abstract concepts, but represent different social groups competing to extend their influence over political authority. A religious leader might react first against established authority out of personal or factional interest or ambition, or he might be a channel for the expression of social discontents. Yet very soon leaders of heterodox movements will often aspire to political power. Normally, religious leaders from local hagiocracies sooner or later will evolve into pillars of the established order and the society at large.

Every Church, having been a sect itself at its beginnings, that is, a movement of social and religious protest breaking with society at large, ends up being reconciled with the latter. As Bryan Wilson has argued, the first stage of this process normally occurs at the second generation of members. Characteristically, there is a loss of the original spontaneity in all fields, the creation of professional ministries, the adoption of oaths, a positive attitude toward society at large and the acceptance of pluralism. This transformation parallels the access of members of the group to respectable social status, whereas the sects, originally very much in reaction against society at large, soon become established when the second generation takes the reins, even though there will always be a first generation to be recruited in a sect. ${ }^{67}$

Protest may come from inside a recognised religious group and establish an ecclesiola in Ecclesia, a religious order, collegium pietatis, characterised by mysticism as in the case of Bektashism. But it may also lead to dissidence, in which case we often observe the formation of ecclesiastic bodies of the Church type, or of semiecclesiastic bodies such as autonomic Churches or, again, of new sects, ${ }^{68}$ to which ecclesiastic and theological terminology will preferably refer as either schism or heresy, and recent political discourse as fundamentalism.

In the case of the reformist vision of revived forms of Islam, ${ }^{69}$ this takes as its ideal the integration of religious and political authority, including an activist political concept of Islam - active commitment to destroy corrupt versions of Islam and bring into being an ideal Muslim community modelled on the example of the Prophet. Such an ideal may spread first in religious circles, but it makes soon a wide social impact, the reformers being particularly effective in organising religious movements in transition societies. Many examples of reformist movements in lineage or tribal societies the world over did lead this way to the formation of states dedicated to the integration of political and religious authority. ${ }^{70}$ Similarly, 
the contemporary Islamic revival, the so-called fundamentalist movements are inspired by the vision of a prophetic community. They attempt to return to the principles of Islamic morality and to a renewal of personal commitment to the symbolic foundations of Islam. They commonly aim to control the state and to use the power of the state to enforce what is believed to be the true Islam. Still, the constant tension that subsists between orthodoxy and mystical movements is not exclusive to Islam. The polemic against sects and heterodox religious movements is primarily and essentially expressed in terms of conflict on doctrinal grounds. If the sociological perspective points to the economic and social roots of religious movements, it tends to underestimate the importance of the religious structure itself. Up to now, the ideological and doctrinal field has been left exclusively in the hands of theologians, occasionally disputed by Orientalist and Medievalist historians. I have discussed elsewhere the particular affinity that sociologists and anthropologists have always shown between new religious movements and social, cultural and national crisis movements. ${ }^{71}$ The analysis of doctrinal-ideological and structural-organisational characteristics of Bektashism in Albanian context that I presented here is an illustrative suggestion that it is precisely on these structural and ideological grounds that a dialectical correlation may be correctly addressed.

\section{Notes}

1. Roland Barthes, "Le mythe aujourd'hui," in Oeuvres complètes (Paris: Seuil, [1957] 1993), pp. 681-719.

2. Herman Bausinger, Volkskunde: von der Altertumsforschung zur Kulturanalyse (Tübingen, 1979).

3. Suraiya Faroqhi, "Conflict, accommodation and long-term survival: the Bektashi order and the Ottoman state (sixteenth-seventeenth centuries)," in Bektachiyya: études sur l'ordre mystique des Bektachis et les groupes relevant de Hadji Bektach, ed. Alexandre Popovic and Gilles Veinstein (Istanbul: Isis, 1995), pp. 171-184.

4. Pierre Bourdieu, "Genèse et structure du champ religieux," Revue Française de Sociologie, vol. 12, no. 3 (1971), pp. 295-334.

5. Ahmet T. Karamustafa, God's unruly friends: Dervish groups in the Islamic later middle period 1200-1550 (Salt Lake City: University of Utah Press, 1994).

6. Irene Melikoff, Hadji Bektach, un mythe et ses avatars: genèse et évolution du soufisme populaire en Turquie, Islamic History and Civilization, 20 (Leiden: Brill, 1998).

7. Irene Melikoff, Sur les traces du Soufisme turc: recherches sur l'Islam populaire en Anatolie, Analecta Isisiana, 3 (Istanbul: Isis, 1992); Alexandre Popovic and Gilles Veinstein, eds., Bektachiyya: études sur l'ordre mystique des Bektachis et les groupes relevant de Hadji Bektach (Istanbul: Isis, 1995).

8. John K. Birge, The Bektashi order of dervishes (London: Luzac Oriental, 1937; reprint, 1994).

9. Melikoff, Sur les traces du Soufisme turc: 163-174; Popovic and Veinstein, eds., Bektachiyya: 39-53.

10. Irene Melikoff, Au banquet des Quarante: exploration au coeur du Bektachisme-Alevisme, Analecta Isisiana, 50 (Istanbul: Isis, 2001): 97-120.

11. Ahmet Yashar Ocak, "Un aperçu général sur l'hétérodoxie musulmane en Turquie: réflexions sur les origines et les caractéristiques du Kizilbachisme (Alevisme) dans la perspective de l'histoire," in Syncretistic religious communities in the Near East, ed. Krisztina Kehl-Bodrogi, Barbara KellnerHeinkele, and Anke Otter-Beaujean, Numen Studies in the History of Religions, 76 (Leiden: Brill, 1997), pp. 195-204.

12. Mehmed Fuad Koprulu, Islam in Anatolia after the Turkish invasion, trans. Gary Leiser (Salt Lake City: University of Utah Press, [1922] 1993): 76-77.

13. Krisztina Kehl-Bodrogi, Die Kizilbash/Aleviten: Untersuchungen uber eine esoterische Glaubensgemeinschaft in Anatolien, Islamkundliche Untersuchungen, 126 (Berlin: Klaus Schwarz Verlag, 1988): $42-47$.

14. Hans-Joachim Kissling, "Zur Frage der Anfänge der Bektaschitums in Albanien," Oriens, vol. 15 (1962), pp. 281-285; Georg Stadtmüller, "Der Derwischorden der Bektaschi in Albanien," in Serta Slavica: In Memoriam Gedenkschrift für Alois Schmaus, ed. Wolfgang Gesemann and Johannes Holthusen, Südosteuropa Verlagsgesellschaft (München: Trofenik, 1971), pp. 683-688. 
15. Nathalie Clayer, L'Albanie, pays des derviches: les ordres mystiques musulmans en Albanie à l'époque postottomane, 1912-1967, Balkanologische Veröffentlichungen, 17 (Wiesbaden: Harrassowitz, 1990); Id., Religion et nation chez les Albanais (XIXe-XXe siècles), Analecta Isisiana, 64 (Istanbul: Isis, 2002).

16. Machiel Kiel, "A note on the date of the establishment of the Bektashi order in Albania: the cult of Sari Saltik Dede in Kruja attested in 1567-1568," in Bektachiyya: études sur l'ordre mystique des Bektachis et les groupes relevant de Hadji Bektach, ed. Alexandre Popovic and Gilles Veinstein (Istanbul: Isis, 1995), pp. 269-274.

17. Albert Doja, "The politics of religion in the reconstruction of identities: the Albanian situation," Critique of Anthropology, vol. 20, no. 4 (2000), pp. 421-438.

18. Albert Doja, "Morphologie traditionnelle de la société albanaise," Social Anthropology: Journal of the European Association of Social Anthropologists, vol. 7, no. 1 (1999), pp. 37-55.

19. Clayer, Religion et nation chez les Albanais: 103-135.

20. J. Spencer Trimingham, The Sufi orders in Islam (Oxford: Clarendon, 1971; reprint, 1998); Karamustafa, God's unruly friends.

21. Edmund Leach, "Melchisedech and the Emperor: icons of subversion and orthodoxy," Proceedings of the Royal Anthropological Institute, (1972), pp. 5-14.

22. Albert Doja, "Histoire et dialectique des idéologies et significations religieuses," European Legacy: Journal of the International Society for the Study of European Ideas, vol. 5, no. 5 (2000), pp. 663-686.

23. Albert Doja, "Confraternal religion: from liberation theology to political reversal," History and Anthropology, vol. 14, no. 4 (2003), pp. 349-381.

24. Birge, The Bektashi order of dervishes: 102-103.

25. Ibid.: 96-97.

26. Harry T. Norris, Islam in the Balkans: religion and society between Europe and the Arab world (London: Hurst, 1993): 97.

27. Doja, "Confraternal religion."

28. Trimingham, The Sufi orders in Islam: 102-104.

29. Irene Melikoff, Au banquet des Quarante: exploration au coeur du Bektachisme-Alevisme, Analecta Isisiana, 50 (Istanbul: Isis, 2001): 141.

30. Frances Trix, Spiritual discourse: learning with an Islamic master, Conduct and Communication Series (Philadelphia, PA: University of Pennsylvania Press, 1993): 103.

31. Kadri Halimi, "Dervishët dhe tempujt e tyre në përgjithësi dhe në Kosovë [Dervishes and their institutions in Kosovo]," in Trajtime dhe studime etnologjike [Ethnological studies and analyses] (Prishtina, Kosova: Instituti Albanologjik i Prishtinës, 2000), pp. 69-142: 76.

32. Edward E. Evans-Pritchard, The Sanusi of Cyrenaica (Oxford: Clarendon, 1949): 3.

33. Joachim Wach, Sociology of religion (Chicago: University of Chicago Press, 1958).

34. Max Weber, Economy and society: an outline of interpretive sociology, ed. Guenther Roth and Claus Wittich (Berkeley: University of California Press, 1978 [1922]): 246-254.

35. Peter J. Bumke, "Kizilbash-Kurden in Dersim (Tunceli, Türkei): Marginalität und Häresie," Anthropos: International Review of Anthropology and Linguistics, vol. 74, no. 3-4 (1979), pp. 530-548; JeanFrançois Bayart, "La question Alevi dans la Turquie moderne," in L'Islam et l'État dans le monde aujourd'hui, ed. Olivier Carré (Paris: Presses Universitaires de France, 1982), pp. 109-120; Krisztina Kehl-Bodrogi, Vom revolutionären Klassenkampf zum 'Wahren' Islam: Transformationsprocesse im Alevitum der Turkei nach 1980, Socialanthropologische Arbeitspapiere, 49 (Berlin: Freie Universität, 1992); Karin Vorhoff, Zwischen Glaube, Nation und neuer Gemeinschaft: Alevitische Identität in der Türkei der Gegenwart, Islamkundliche Untersuchungen, 184 (Berlin: Klaus Schwarz Verlag, 1995); Erhard Franz, "Religion und Gesellschaft in der Türkei: Laizismus contra Islamismus in Gesellschaft und Politik," in Religion und Gesellschaft in Südosteuropa, ed. Hans-Dieter Döpmann, SüdosteuropaJahrbuch, 28 (München: Südosteuropa-Gesellschaft, 1997), pp. 299-307; Elise Massicard, L'autre Turquie: Le mouvement aléviste et ses territoires (Paris: Presses universitaires de France, 2005).

36. Frederick W. Hasluck, Christianity and Islam under the Sultans (Oxford: Clarendon, 1929; reprint, Istanbul: Isis, 2000): 428-442.

37. Clayer, Religion et nation chez les Albanais: 151-158.

38. Stavro Skendi, The Albanian national awakening, 1878-1912 (Princeton: Princeton University Press, 1967): 469-470.

39. Peter Bartl, Die albanischen Muslime zur Zeit der nationalen Unabhängigkeitsbewegung, 1878-1912, Albanische Forschungen, 8 (Wiesbaden: Harrassowitz, 1968).

40. Roberto Morozzo della Rocca, Nazione e religione in Albania (1920-1944) (Bologna: Mulino, 1990).

41. Norbert Jokl, “Die Bektaschis von Naim Frashëri,” Balkan-Archiv, vol. 2 (1926), pp. 226-256.

42. Zija Xholi, Naim Frashëri midis së kaluarës dhe së sotmes [Naim Frashëri between past and present] (Tirana: Luarasi, 1998). 
43. Ger Duijzings, Religion and the politics of identity in Kosovo (London: Hurst, 2000): 157-175.

44. Georg Stadtmüller, "Der Derwischorden der Bektaschi in Albanien," in Serta Slavica: In Memoriam Gedenkschrift für Alois Schmaus, ed. Wolfgang Gesemann and Johannes Holthusen, Südosteuropa Verlagsgesellschaft (München: Trofenik, 1971), pp. 683-688.

45. Albert Doja, "Confraternal religion: from liberation theology to political reversal," History and Anthropology, vol. 14, no. 4 (2003), pp. 349-381: 360-368.

46. Clayer, Religion et nation chez les Albanais: 103-135.

47. Ali Turabiu, Historia e pergjithshme e Bektashinjvet (Tirana, 1929).

48. Clayer, Religion et nation chez les Albanais: 155-156.

49. Halimi, "Dervishët dhe tempujt në Kosovë."

50. Alexandre Popovic, L'islam balkanique: les musulmans du sud-est européen dans la période post-ottomane, Balkanologische Veröffentlichungen, 11 (Wiesbaden: Harrassowitz, 1986); Clayer, L'Albanie, pays des derviches: $47-67$.

51. Much more recently, in the time of post-communist transition, it was the head of the Orthodox Church that was expelled with a deportation order while the head of the Islamic Association has been murdered again in what some believe was an assassination by the fundamentalist faction to gain control of the direction of Islam in Albania.

52. Trimingham, The Sufi orders in Islam: 80; Norris, Islam in the Balkans: 89.

53. Trix, Spiritual discourse: 33-34.

54. Vittoria Luisa Guidetti, "Elementi dualistici e gnostici della religione Bektashi in Albania fra il XVII e il XIX secolo," in Destino e salvezza: tra culti pagani e gnosi cristiana. Itinerari storico-religiosi sulle orme di Ugo Bianchi, ed. Giulia Sfameni Gasparro (Cosenza: L. Giordano, 1998), pp. 239-264: 264. Two of these manuals, Kitabu irsadul muridin (the book of initiation) and Tarikatname (brotherhood's statutes), deposited in the National Library of Naples (Italy), have been recently translated into Italian and analysed for a Laurea thesis in historical-religious studies.

55. Metin Izeti, Tarikati Bektashian (Tetova, Macedonia: Çabej, 2001): 53-55.

56. Melikoff, Au banquet des Quarante: 121-133.

57. Birge, The Bektashi order of dervishes: 107.

58. Baba Rexhebi, Misticizma Islame dhe Bektashizma (New York: Waldon Press, 1970).

59. Izeti, Tarikati Bektashian: 53-55.

60. Jashar Rexhepagiqi, Dervishët, rendet dhe teqetë në Kosovë, në Sanxhak e në rajonet e tjera përreth, në të kaluarën dhe sot [Dervishes, Orders and their Institutions in Kosovo, Sandjak and around, in the past and today] (Peja, Kosova: Dukagjini, 1999): 258.

61. Clayer, L'Albanie, pays des derviches: 77-78; Norris, Islam in the Balkans: 94.

62. Henry Corbin, L'homme de lumière dans le soufisme iranien (Paris: Éditions Présence, 1971); Id., Corps spirituel et Terre céleste: de l'Iran mazdéen à l'Iran chiite, 2e ed. (Paris: Buchet-Chastel, 1979); Id., Temps cyclique et gnose ismaélienne (Paris: Berg Publishers, 1982); Id., Face de Dieu, face de l'homme: herméneutique et soufisme (Paris: Flammarion, 1983).

63. Alexandre Popovic and Gilles Veinstein, eds., Les voies d'Allah: les ordres mystiques dans l'Islam des origines à aujourd'hui (Paris: Fayard, 1996): 468-474.

64. Rajwantee Lakshman-Lepain, "Albanian Islam: development and disruptions," in Albania, a country in transition: aspects of changing identities in a South-East European country, ed. Frank Kressing and Karl Kaser, Schriften des Zentrum für Europäische Integrationsforschung, 51 (Baden-Baden: Nomos, 2002), pp. 39-64: 54.

65. Hans-Joachim Kissling, "The sociological and educational role of Dervish Orders in the Ottoman Empire," in Studies in Islamic cultural history, ed. Gustave E. Grunebaum, Memoirs of the American Anthropological Association, 76 (1954), pp. 23-35: 25.

66. Nehemia Levtzion, ed., Conversion to Islam (New York: Holmes \& Meier, 1979): 213.

67. Bryan R. Wilson, The social dimensions of sectarianism: sects and new religious movements in contemporary society (Oxford: Clarendon/Oxford University Press, 1990).

68. Wach, Sociology of religion.

69. John O. Voll, Islam: continuity and change in the modern world (Syracuse, N.Y.: Syracuse University Press, 1994).

70. Evans-Pritchard, The Sanusi of Cyrenaica; Clifford Geertz, The religion of Java (Glencoe, Ill.: Free Press, 1960); James L. Peacock, Muslim puritans: reformist psychology in Southeast Asian Islam (Berkeley: University of California Press, 1978).

71. Doja, "Histoire et dialectique des idéologies et significations religieuses," 677-679. 